\title{
DİN FELSEFESİ AÇISINDAN HRISTIYYALIKTAKİ CEHENNEM İNANCINA GENEL BİR BAKIŞ
}

\section{öz}

Yahudilik, Hristiyanlık ve İslam gibi teistik dinler arasında gerek inanç esasları gerekse Tanrı anlayışı açısından bazı önemli farklar olmasına rağmen, Tanrı'nın birçok sıfatında, cehennemin varlığı ve orada çekilecek ceza konusunda görüş birliği olduğunu görürüz. Konumuzu ilgilendiren bu sıfatlar Tanrı'nın Kâdir-i Mutlak, Mutlak Adalet sahibi, Mutlak Âlim, Salt İyi, Merhamet sahibi Ebedi olması sıfatlarıdır. Fakat cehennemin teolojik tasvirlerini bu sıfatlara sahip bir varlık ile beraber düşündüğümüzde ortaya bazı problemlerin çıktı̆ı açıktır. Çünkü bir dindar için tanrısal iyilik sadece dünyevi iyilik şeklinde algılanmaz. 0 , bu iyiliği metafizik ve aşkın bir tarzda da anlayarak onun anlam içeriğini çok daha farklı ve geniş tutabilir. Aynı şeyler adalet sıfatı için de söylenebilir. Tanrısal adalet sadece "göze göz dişe diş" şeklindeki eşitlikçi ve dengeleyici bir hukuk ilkesi olarak yorumlanmayabilir. Yine bazılarına göre merhametli bir Tanrı tasavvuru ile cehennemdeki korkunç işkenceler ve hem de bunların ebedi olarak yaşanacak olması Tanrı'nın merhamet sıfat ile ilgili bazı sorunları beraberinde taşıyabilir. Ebedi cehennem inancı ile ilgili bazı teolog ve kelamcılar Allah dışında hiç bir varlığın bâki kalma vasfina haiz olamayacağı itirazını dile getirmişlerdir. Nasıl ki ezelde hiçbir şey Zât-ı Bârî ile beraber değildi ise, ebedde de böyle olacak, Allah'tan gayrı bir mevcut bulunmayacaktır.

\section{anahtar kelimeler}

Hristiyanlık, Teizm, Cehennem, Din Felsefesi, Tanrı, Adalet, İyilik, Merhamet, Sevgi. 


\section{A General Overview on the Christianity's Belief in Hell on the Basis of the Religion Philosophy}

\section{abstract}

Although there are some important differences between the theological religions such as Judaism, Christianity and Islam, both in terms of faith rudiments and God understanding, we see that there is a consensus in many of God's attributes and about the existence of hell and the punishment in hell.1 These attributes which concern our subject are God being Omnipotent, Absolute Justice, Absolute Wise, Pure Good, Mercy, Eternal. But when we consider the theological depictions of hell together with an entity with these attributes, it is clear that some problems occur. For a religionist, deific goodness is not only perceived as secular goodness. By understanding this kindness metaphysically and transcendently, He can keep its meaning much more diverse and wide. The same can be said fort he attribute 'justice'. Deific justice may not only be interpreted as an equitable and balancing law principle in the form of "an ey efor an eye and a tooth for a tooth". Again, according to some, with a compassionate God vision, the terrible tortures in the hell, and their eternal living, may arise some problems about God's compassion. Some theologians hell have expressed the objection that no entity other than Allah can be vested with being everlasting, related to the belief about eternal hell faith. Just as nothing had ever been with Supreme Being in preeternity, it would be so in post eternity, and there would be no existence except Allah.

\section{keywords}

Christianity, Theism, Hell, Philosophy of Religion, God, Justice, Goodness, Mercy, Love.

\section{Giriş}

Din felsefesi dini inançlar üzerinde akıl düzleminde ortaya konulan rasyonel ve eleştirel bir düşünme faaliyetidir. Eskatoloji ya da 'ölümden sonra hayat' konusu dinlerin temel inançlarından biri olduğu için din felsefesinin bu konuya bigâne olması elbette beklenemez. En nihayetinde bu konu hayatın anlamı, niçin var olduğumuz gibi varoluşsal konularla birlikte iyilerin ödüllendirilmesi, kötülerin cezalandırıması gibi ahlaki tartışmaları içerisinde barındırmaktadır. Cehennem inancı aynı zamanda kişinin sahip olduğu Tanrı tasavvuruyla da yakından ilgilidir. Dolayısıyla bu konu Tanrı-insan ilişkisini de içine alan önemli bir konudur. Tanrı'nın sıfatlarından 'adalet' sıfatını ön plana çıkartanlar için cehennem inancı başka bir şekilde anlaşılırken, merhamet ya da sevgi sıfatını ön plana çıkartanlar için daha başka anlaşılabilmektedir. Bu makalede amacımız teistik bir din olan Hristiyanlıktaki cehennem inancının mahiyeti ve bu inanç etrafinda din felsefesi literatüründe ortaya çıkan tartışmaları ve temel görüş- 
leri ele almaktır. Din felsefesi literatürü açısından söylersek Hristiyan dünyada cehennem inancı etrafinda ortaya çıkan tartışmalar halen canlılığını korumakta ve bu konu üzerinde birçok makale, kitap ve tez yazılmaktadır.

Yahudilik, Hristiyanlık ve İslam gibi teistik dinlerin en önemli inanç esaslarından biri olan ölümden sonraki yaşam çağdaş din felsefesinde genellikle yeniden diriliş konusu çerçevesinde tartışılmış, böyle bir dirilişin olup olmayacağı, eğer varsa bu dirilişin ruhen mi yoksa bedenen mi olacağı, kişisel kimlik problemi gibi konular üzerine odaklanılmıştır. Oysa bu yaşamın en önemli unsurları olan cennet ve cehennem inancının çok fazla tartışma konusu edilmediğini ve din felsefesi ile ilgili çalışmalarda belirgin bir şekilde yer almadığını görmekteyiz (Akdemir, 2013a: 132-133).

Biyolojik ve kozmik kökenlerimiz hakkında görüş beyan edilmesi gerektiğinde, inananlar sadece aile ya da ulus değil, nihai olarak "Tanrı'dan" geldiklerini ifade ederler. Aynı şekilde evrenin ve içindekilerin de Tanrı'ya döneceği ifade edilir (Hayes, 1996: 91-92). Ölüm sonrası hayat veya öldükten sonra hesaba çekilme düşüncesi ve inancı, insanlık tarihi boyunca zihinleri hep meşgul etmiş, semavi ve gayr-ı semavi hemen hemen bütün dinler bu inancı insanlara temel bir inanç önermesi olarak sunmuşlardır. Bazı dinlerde ve inanışlarda farklı farkIı isimlerle anılsa da, iyilerin gideceği yere cennet, kötülerin cezalandırılacağı yere de cehennem adı verilir (Tunçbilek, 2006: 15). Kelime olarak derin kuyu anlamına gelen cehennem, azaba müstahak olan kulların azap görecekleri ateşin veya yerin adıdır (Tunçbilek, 2006: 16).

Geleneksel teizmin karşı karşıya kaldığı en çetin zorluklardan biri kötülük problemidir. Bazılarına göre Yahudilik, Hristiyanlık ve İslam'da yani bu üç dinin inanç sisteminde dünyada var olandan farklı bir kötülük türü daha vardır. Bu özel türden kötülük, bazı insanların sonsuza kadar berbat bir işkence içinde cehennemde kalacağıdır. Geleneksel görüşe göre cehennemde olmak bir kişinin başına gelebilecek en kötü şeydir. İlk soru böyle bir kötülüğün nasıl haklı çıkarılabileceği ile ilgilidir (Kvanvig, 1993: 3). Kötülük sorunu ateistlerin cephaneliğindeki ana silahlardan biridir. Soru basit bir biçimde şu şekilde ifade edilir: Kötülük ve ıstırabın varlığı, kusursuz bir sevgi ve güç Tanrısının varlığı ile nasıl uyumlu olabilir? Bu yaşamdaki kötülüğün varlığını anlamlandırmak zor iken, cehennem inancı bu anlamlandırma zorluğunu, acıyı ve sefaleti asla bitmeyen bir sonraki yaşamın içine uzatıyor. Bu korkutucu olasılık rasyonel ateistlerin gözünden kaçmamıştır. Çünkü birisi Truvalı Helen'in gerçekten var olup olmadığını pek merak etmeyebilir. Ama cehennem ile ilgilenmemek bambaşka bir meseledir. Cehennemin varlığı hayatımızı derinden etkileyen varoluşsal merkezi önemde bir sorundur (Walls, 2009: 100).

Yahudilik, Hristiyanlık ve İslam gibi teistik dinler arasında gerek inanç esasları gerekse Tanrı anlayışı açısından bazı farklar olmasına rağmen, Tanrı́nın bir- 
çok sıfatında, cehennemin varlığı ve orada çekilecek ceza konusunda neredeyse bir görüş birliği olduğunu görürüz (Wierenga, 1989: 1). Konumuz açısından önemli olan bu sıfatlar: Tanrı'nın mutlak kâdir, mutlak adil, salt iyi, (Peterson, v.dğr., 2006: 87), merhamet sahibi (Swinburne, 1993: 56), ebedi olması (Leftow, 2010: 278), çok seven (Gale, 1996: 285) bir varlık olduğunu gösteren sıfatlardır. Cehennem tasvirlerini bu sıfatlara sahip bir varlık ile beraber düşündüğümüzde ilk bakışta bazı problemlerin var olduğu açıktır. Çünkü bir dindar için tanrısal iyilik sadece dünyevi iyilik şeklinde algılanmaz. $O$, bu iyiliği metafizik ve aşkın bir tarzda da anlayarak onun anlam içeriğini çok daha farklı ve geniş tutabilir. Aynı şeyler adalet sıfat için de söylenebilir. Tanrısal adalet sadece "göze göz dişe diş" şeklindeki eşitlikçi ve dengeleyici bir hukuk ilkesi olarak yorumlanmayabilir. Bir dindarın gözünde tanrısal adalet, mutlak bilgi ve kudretle ilişkilendirildiğinde farklı, hatta insanın sahip olduğu dünyevi bilişsellik yeteneği ile bilemeyeceği yeni anlam içeriklerine kavuşabilir. Yine bazılarına göre merhametli ve seven bir Tanrı tasavvuru ile cehennemdeki korkunç işkenceler ve hem de bunların ebedi olarak yaşanacak olması Tanrı'nın merhamet ve sevgi sıfat ile ilgili bazı sorunları bünyesinde barındırabilir (Akdemir, 2013a: 154).

Cehennem inancı din felsefesinde her zaman tartşııımış ve filozofların dikkatini çekmiştir (Seymour, 1997: 249). Felsefe tarihinde birkaç filozofun bu konuda söyledikleri bile aslında konunun etraflıca ele alınması gereken bir konu olduğunu gösteriyor. Bir mükâfat ve ceza yeri olarak öte dünyadan, Platon'un yüzyıllardır okunan eserlerinde uzun uzun bahsedilmiştir (Eflâtun, 1989: 3,1415). Hristiyanlığın cehennem doktrini belki varlığını Platon'a borçlu değil ama Hristiyan Platonculuğunun bu inançları güçlendirmeye katkı yaptığı da açıktır (Burkert, 2009: 147).

Cehennem inancı hakkında ateistler ve Hristiyanlığın diğer eleştirmenleri tarafindan yüzlerce yıldır esaslı itirazlar ortaya konulmuştur (Walls, 2009: 100). Cehennem öğretisinin pek çok insanı nasıl rahatsız ettiğini görmek zor değildir. İnsanlar büyük acılarla dolu böyle bir kötülüğe Tanrı'nın nasıl izin vereceğini doğal olarak sorarlar. Cehennemin acıları hayal edildiğinde ve bir de oradaki işkencenin ebedi olduğu düşünüldüğünde bu soru ısrarla sorulur (Seymour, 2007: 1). Örneğin Richard Dawkins'in The God Delusion adlı kitabında cehennem ile ilgili olan tartş̧mayı büyük ölçüde cehennem inancı etrafinda ortaya konulmuş irrasyonel korkulara odaklaması dikkat çekicidir. Dawkins vaizler ve rahiplerin cehennemle ilgili betimlemelerinin Tanrı'ya iman edenleri bile psikolojik olarak rahatsız ettiğinden ve bu kişilerin neredeyse korkudan dolayı travmatize olmuş öykülerinden bahseder (Dawkins, 2006: 321). Dawkins bu konuda şunları söyler:

Öğretmenlerin ve rahiplerin çocuklara, ebedi bir cehennemde günahlarından dolayı cezalandırılacaklarına inanmaya teşvik etmelerinin ne olduğunu söylemek gerekirse, bunun için "çocuk istis- 
marı" ifadesinin kullanılmasının abart olmadığını düşünüyorum (Dawkins, 2006: 318). Cehennem ateşi korkusu, rasyonel insanlara bile çok gerçekçi gelebilir. Televizyon belgeselimden sonra, aldığım birçok mektup arasında, zihni açık ve dürüst olduğu belli olan bir kadının mektubu da vardı. Bu kadın mektubunda şunları yazıyordu: "Beş yaşından itibaren bir Katolik okuluna gittim ve kayışları, sopaları ve köpekleri olan rahibeler tarafindan beynim yıkandı. Gençliğim boyunca Darwin'i okudum ve evrim hakkında söyledikleri bana mantkklı geldi. Bununla birlikte, yaşamdaki tezatlardan ve cehennem ateşinden derin bir korku duydum. Daha önce bu problemlerin üstesinden gelmek için bazı psikoterapi seansları almıştım ama artkk bu derin korkunun üstesinden gelemiyorum." (Dawkins, 2006: 321)

Dawkins'e göre cehennemin varlığına inananlar, başkalarının lanetlenmesinden zevk alan daima kendini beğenen ikiyüzlülerdir (Walls, 2009: 101). Her halükarda, Dawkins'in cehenneme yaklaşım tarzı, Nietzsche'den beri popüler olan fikrin bir çeşididir ki Nietzsche bunu "Ahlakın Soykütüğü Üzerine" adlı eserinde ele almış (Nietzsche, 2008: 29) ve bu, postmodern düşüncede son derece etkili olmuştur. Ona göre, nezaket, affetme ve merhamet gibi Hristiyan ahlaki idealler, zayıf insanların güçlüler üzerinde bir avantaj elde etmeleri için gerçekten zekice kurgulanmış bir oyundur. Herkes, bilinçli olsun ya da olmasın, "güç istemi" doğrultusunda hareket ediyor. Zavallılar için merhametten bahsedenler ve ezilenlere hizmet edenler, bu dünyanın elitleri üzerinde dolambaçlı bir manipülasyon ve kontrol biçimine giriyorlar. Aynı şekilde, Nietzsche, Hristiyan inançları olan cennetin ve cehennemin, zayıf ve dürüst olmayan insanların güçlü düşmanlarından intikam almalarının bir biçimi olduğunu düşünüyordu (Walls, 2009: 101).

J. Stuart Mill'e göre bu (Hristiyanlıktaki) Tanrı, cehennemi insanın çoğunluğunun kaderi olacağını bilerek yaratt; dürüst olacaksak böyle bir Tanrı iyi ve adil olarak kabul edilemez (Mill, 2009: 18). O şöyle devam eder:

Vahyin kendisinde yer alan ahlaki zorluklar ve sapkınlıklardan bahsetmiyorum; İncil Hristiyanlığı içinde, en azından sıradan yorumuyla, İsa'nın sözlerini ve karakterini oluşturan tüm güzelliği, iyi huylu ve ahlaki büyüklüğünü neredeyse her yönden aşacak kadar açık bir mahiyet vardır. Örneğin, cehennemi yaratabilen bir varlık, en yüksek ibadet nesnesi olarak görülür, yine bu varlık böyle bir kader (cehennem) için sayısız nesiller yaratır. Doğru ve yanlış bir standardın dehşet çarpıklığı olmadan böyle bir şeye tapmak mümkün mü? Hristiyanlığın bu ortak kabülünde yer alan Tanrı'nın ahlaki karakteri yanında, en sıradan adaletsizlikler ve in- 
sanlığa olan zulümler, önemsizliğe gömülüyor (Mill, 2009: 132). Cehennemi yaratabilecek böyle bir varlı̆ıın hem insan ırkını yanılmaz önbilgiyle yarattı̆ı savunuluyor ve hem de onların büyük bir çoğunluğunu korkunç ve sonsuz olan bir işkenceye göndereceği iddia ediliyor (Mill, 2009: 219). İ̆renç anlayışa bakın ki bir yandan milyarlarca insanı yaratan bu varlık, diğer yandan onlara sonsuza kadar eziyet etmek için cehennemi yaratiyor (Mill, 2009: 224).

Yukarıda örneklerini verdiğimiz filozoflara göre temelinde nefret ve kin bulunan cehennem inancı irrasyonel olduğu için kınanmalı ve reddedilmelidir. Fakat diğer taraftan cehennem ile ilgili böyle düşünenlerin gözden kaçırdığı bir durum vardır ki o da en nihayetinde cehennem ve onunla ilgili inancın, insanları iyi insan haline getirmek için var olduğudur (Walls, 2009: 101-102).

Cehennem ile ilgili neredeyse son iki asırda ateist düşünürlerin dışında ortaya çıkan fikirler, genellikle Tanrı'nın sevgi dolu bir varlık olduğu konusuna odaklanırlar ve cehennemin nasıl bir yer olduğunu tanımlarken yine Tanrı'nın sevgi dolu karakterine daha fazla dikkat edilmesi gerektiğini iddia ederler. Oysa cehennem hakkındaki gelenekselci fikirler cenneti ve cehennemi açıklamada Tanrı'nın farklı sıfatlarına işaret ederler. Bu görüşte olanlara göre cennet genellikle Tanrı'nın sevgisiyle açıklanırken cehennem daha ziyade Tanrı'nın adaleti ile açıklanır (Kvanvig, 1993: 109).

Özelikle son yıllarda Hristiyanların çoğunun sonsuz ceza kavramıyla ilgili sorunları vardır. Bu ilk bakışta doğal bir şey gibi görünür. Çünkü Kutsal Kitabı okuduklarında onlara Tanrı'nın, günahları için çarmıhta ölen, göğe yükselen ve ona güvenen herkese lütuf ve bağışlama sağlayan, sevgi dolu bir kurtarıcı olduğu öğretilmiştir. İnsanlar sonsuza kadar cezalandırılıyor ve üstelik Yahudi ve Müslümanlar da bu görüşü kabul ediyorlarsa sevecen, merhametli bir Tanrı anlayışını adil ve affetmeyen bir Tanrı ile nasıl uyumlu hale getirebiliriz? Böyle düşünenler için aslında olması gereken, ebedi intikamı düşünen Tanrı yerine sevgi dolu bir Tanrı'dır (Walvoord, 1996: 11).

\section{Gelenekselci Cehennem İnancına Genel Bir Bakış}

Hristiyan teoloji geleneğinin savunduğu, bu yaşamdan sonra yaptığımız olumsuz şeylere yönelik ceza yani günahkârların günahları için sonsuza kadar cezalandırılacağı inancı, son iki yüzyıl hariç, neredeyse evrensel kabul görmüştür (Swinburne, 1998: 203). Hristiyan dünyada cehenneme ilişkin olarak, detaylarında farklılaşsalar da, karşıt pozisyonda konumlanmış iki ana görüş olduğunu söyleyebiliriz. İlki, Augustine zamanından 19. yüzyıla değin Hristiyan teolojisinde egemen olan cehennemin de cennetin de ebedi olduğu ve küfür/inkâr halindeki günahkâr ruhların sonsuza kadar cehennemde kalmaya mahkûm olduğu şeklindeki Gelenekselci Cehennem Inancı, diğeri ise cehennem hayatının 
sonsuz olmadığı, bütün günahkâr ruhların günahları ne olursa olsun cezalarını çektikten sonra cennetteki yaşama katılacağı ve İsa ile buluşacağı şeklindeki Evrenselci Cehennem Inancı'dır (Akdemir, 2013b: 120). Bu iki ana görüş dışında özellikle son yıllarda Thomas Talbott gibi filozof ve Clark H. Pinnock gibi teologlar tarafindan ileri sürülen farklı görüşler de vardır.

Gelenekselci görüşte cehennemin yaratılışı anlatılırken ilk olarak Tanrı'nın kendi dışında her şeyi yarattı̆ına vurgu yapııır. Tanrı özgür iradeli varlıklar olarak insanı yarattğında, cehennemi de yaratmıştır. Bu da dolaylı olarak şu anlama geliyor: Tanrı'nın insana verdiği özgürlükle ilişkili olarak, insanın Tanrı́yı sevmeme, Ona güvenmeme ve Ona itaat etmemeyi tercih etme imkânı vardır. Bu seçimler yapılır ve bu seçimler üzere yaşamaya devam edilirse, yapılan bu seçimin karşılığı olarak cehenneme gitme olasılığı gerçeğe dönüşür. Yani cehennem, özgür bireylerin özgürlüklerini Tanrı'ya yönelme yönünde değil, onu reddetme yönünde kullanma (seçimlerini kötülüğü tercih ederek yapmaları) intimaline karşı yaratılmıştır. Böyle yaparak, bu insanlar mümkün olan tek mutluluk kaynağını reddetmiş ve böylece hayal kırıklığı, sefalet ve ıstraplara da kendi rızaları ile boyun eğmiş olurlar (Walls, 2009: 104).

Gelenekselci görüşe göre Hristiyanların kutsal kitabı Yeni Ahit'te cehennem ve oradaki azap temel inançlar içerisinde yer alır ve cehennemin ebedi olduğu vurgulanır. İncillerde cehennemin "sönmeyen ateşe", "sonsuz ateşe" "sonsuz cezaya" benzetilmesi bunun apaçık örnekleridir (Tunçbilek, 2006: 18). James İncil'i hariç, cehenneme yapılan tüm göndermeler, bizzat Mesih'ten duyulmuştur ve ölümden sonra kötülerin sonsuza kadar cezalandırılması konusunda bariz bir vurgu vardır (Walvoord, 1996: 20). Vahiy kitabı Tanrı'ya sonsuzluk atfeder ve aynı zamanda Tanrı'nın gazabı sonsuza kadar devam eder (Walvoord, 1996: 26). Ebedi ceza meselesinden kuşkulanmak, ya Tanrı sözü'nden şüphe etmeyi ya da onun basit, normal yorumunu inkâr etmeyi gerektirir (Walvoord, 1996: 26-27).

Gelenekselci görüşe göre Yeni Ahitte yer alan ifadelerden ölümden sonraki hayatta iyilerin hayatının sonsuz olması gibi, kötülerin de hayat da sonsuz olacaktr. Örneğin bir ayette "Sonra solundakilere şöyle diyecek: Ey lanetliler, çekilin önümden! iblis'le melekleri için hazırlanmış sönmez ateşe gidin"1 denilerek cehennemin kötüler için hazırlanmış sonsuz bir yer olduğuna vurgu yapılır. Temel Hristiyan inançlarının belirlendiği İznik Amentü'sünün ilk satırında yaratılış şöyle özetlenmiştir: "Her şeye gücü yeten Tanrı'ya, yeryüzü ve gökyüzünün yaratıcısına ve görünür olan ve görünmeyen her şeye inanıyoruz." Burada önemli olan iddia, Tanrı'nın kendisinden dışında her şeyi yaratmasıdır. Üstelik yarattğı her şey iyidir. Hristiyanlık için temel olan bu iddia, cehennem hakkındaki kafa karışıklı̆ını artırır. Çünkü Tanrı var olan her şeyi yarattıysa, o zaman cehennemi de yaratmış olmalı ve onun yarattı̆ı her şey iyi ise cehennem de iyi 
olmalı ama açık olan şu ki cehennem iyi bir şey değildir. Kafa karışıklığı görünür ve görünmez her şeyi yaratan Tanrı'nın mahiyeti üzerine düşünüldüğünde iyice $\operatorname{artar}$ (Walls, 2009: 102).

Sınırlı yaşamdaki sınırlı günahın ebedi cezayı hak ettiğini savunan gelenekselci cehennem inancını savunanların başında Augustine, Anselm ve Aquinas gelmektedir. Cehennemi günahların cezası için sonsuz bir işkence yeri olarak benimseyen Augustine "Tanrı'nın Şehri" kitabında, toplumsal olarak kabul edilebilir ceza biçimleriyle analojik karşılaştırmalar yaparak cehennemin ceza olarak adalet ilkesine aykırı bir yer olmadığını savunur (Seymour, 2007: 38-39). Geleneksel cehennem inancının bir öğreti olarak formatının Augustine'e dayandırıldığını görmekteyiz. O, cehennemin, hem beden hem de ruhta gerçekleşecek sonsuz bilinçli bir azap durumu olduğunu iddia eder. Elbette Augustine'nin vizyonunun gücü çok etkilidir ve bin yıldan uzun bir süredir Hristiyan dünyaya egemen olmuştur (Pinnock, 1996: 139). Augustine "Tanrı'nın Şehri" eserinin özellikle 21. bölümünde, cehennemliklerin fiziksel özelliklerini koruyarak ve bilinçlerini de yitirmeksizin sonsuza kadar maddi ve manevi acı çekeceklerini fantastik bir dille anlatır. Bu anlatılar, yakın zamanda ölen ünlü teolog Clark $\mathrm{H}$. Pinnock'a göre, tarihsel süreç içerisinde Hristiyanlığın cehenneme ilişkin öğretisel inancı haline gelmiştir. Ayrıca yine ona göre, bu inancın şekillenmesinde Hristiyanlık öncesi düşüncelerin de etkisi belirleyici olmuştur. Bu noktada itham ettiği düşünce ise mimarını Platon olarak ilan ettiği ruh-beden düalizmidir. "Hellenistik bir inanç" olarak nitelediği bu düşünce ona göre, eskatoloji konusundaki Hristiyan zihnini/dünyasını Hristiyanlığın başlangıcından beri hep domine etmiştir. Platon'a göre, ruh ve beden bölünemeyen, parçalanamayan ve birbirine indirgenemeyen iki ayrı töz idi. Dolayısıyla insan her ne kadar dünyevi anlamda ölümlü ise de, ruhsal olarak ölümsüzdür; onun ruhu sonsuza kadar varlığını koruyacaktır (Akdemir, 2013a: 140).

Öğretimde de vaazda da soyut imgeler için somut imgeler tercih edilir. Bu nedenle cennete ve cehenneme yapılan kavramsal referanslar somutlaştırılarak sunulur (Crockett, 1996: 54). Çağlar boyunca cehennem betimlemeleri kiliseye egemen olmuştur. Birkaç aykırı düşünce haricinde bu görüş Augustine (5.yy)'den reformculara (16.yy) kadar Hristiyan düşüncesini etkisi altına almıştr. Bu düşünce nihayetinde Luther ve Calvin gibilerinin eleştirileri ile yüzleşmek zorunda kalmıştır (Crockett, 1996: 46). On sekizinci ve On dokuzuncu yüzyıllarda Luther ve Calvin'in uyarılarından sonra bile, önde gelen vaizler ve ilahiyatçılar, cehennemin kötülerin sonsuza kadar yakılacağı bir ateş denizi olacağını düşünmüşlerdir (Crockett, 1996: 48).

Anselm ise sadece adalete vurgu yapmak yerine Tanrı'nın iyiliği ve merhameti ile adaleti arasındaki ilişkiyi farklı bir şekilde açıklamaya çalışır. Ona göre Tanrı, kendi haysiyetini tehlikeye atmayacak şekilde iyidir, Onun mülkünde ölçüsüzlüğün, düzensizliğin yeri yoktur bu yüzden cezasız günah, evrenin ahlaki 
düzenini bozar. Yani bu onun evren için koyduğu nizama uygun değildir. Günahın önemi, kişinin günah işlemek için ödemek zorunda olduğu bedelle ölçülür. Bu bedel sonsuz olduğundan, günah da sonsuz bir negatif değere sahiptir. Günah işlemek Tanrı'ya sonsuz bir şekilde borçlanmaktır. Anselm, günahın sonsuz suçluluğu göz önüne alındığında, günahkârın sonsuz bir cezaya katlanmak zorunda olduğu sonucuna böyle varır. Bu da ona göre cehennemi gerçek bir olasılık haline getirir (Seymour, 2007: 48-49). Anselm'in görüşü, Hristiyan dünyanın ürettiği soteriyolojideki ${ }^{2}$ en ünlü ve en çok eleştirilen felsefi düşüncedir. Bazı filozoflar bu teorideki ahlaki unsurları sakıncalı bulurlar (Seymour, 2007: 49). Talbott'a göre, herhangi bir suça; günaha karşılık gelebilecek hiçbir eşit ceza yoktur. Ona göre Anselm Augustine'nin teorisini kabul etmenin ötesinde çarpıtmış ve sonuç olarak, tüm suçların esasen aynı cezayı gerektirdiği sonucuna varmıştir. Talbott'a göre cehennemde sonsuz işkence inancı, bu intikamcı teorinin temelde en zayıf tarafidır (Talbott, 1993: 160).

Bir sonraki önemli figür T. Aquinas ise cehennemi savunurken bize hem geleneksel hem de özgün argümanlar sunar. Katolik bir filozofa yakışır şekilde Aquinas, kilise babalarının geleneksel konumundan yararlanır. O, eğer insanlar ebedi varlıklar olacaklar ise doğal olarak o zaman ceza da ebedidir görüşünü benimser. Peki adalet argümanı ne olacak, bu argüman varsayımsal olarak sonlu günahlarımızın sonsuza kadar cezalandırılmaya layık olduğu varsayımına meydan okur. Aquinas buna bir örnekle cevap verir. Ona göre devlet bir katili hayat boyu hapse atmak ve tekrar öldürmesine izin vermek arasında bir seçim yapmak zorunda kalsaydı, ömür boyu hapsetme kararı iki kötülükten daha az kötü olanı seçilmiş olduğu için doğru bir karar olurdu (Seymour, 2007: 40).

Yine Leibniz de gelenekselci ekol içinde ebedi ceza inancını destekler (Leibniz, 2007: 208) ve bunu çeşitli şekillerde ifade eder. O, ebedi cehennem gerçekliğini tasdik ederek bazı insanların lanetleneceğini bazılarının ise kurtulacağını tasdikler. Leibniz'in, ebedi ceza inancı lehine görüş bildirdiği şüphe götürmez, ama o böyle bir cezanın gerekçesini net bir şekilde ifade etmez (Strickland, 2009: 309).

\section{Evrenselci Cehennem İnancı ve Cehennem İnancı İle İlgili Diğer Yorumlar}

Çağdaş felsefe ve teoloji çevrelerinde cehennem öğretisi can alıcı bir öneme sahiptir. Geçmiş yüzyılların önemli bir konusu haline geldikten sonra, cehennem inancı, özellikle felsefi teolojinin tekrar ilgisini çekmiştir. Egemen görüş ebedi cezanın kabul edilmemesi olmuştur (Van Holten, 1999: 37). Geleneksel görüş ile ilgili ciddi sorunlar nedeniyle alternatif yorumların önerilmesi doğaldır. Bunları genel özellikleri ile bilmenin konumuz açısından faydalı olacağını düşünüyoruz. 
Evrenselci cehennem inancında bütün günahkar ruhların -günahları ne olursa olsun- cezalarını belli bir süre çekecekleri yani bütün ruhların hepsinin sonunda kurtarılacağı savunulur (Walvoord, 1996: 14). Bu görüşü savunanlara göre kötülerin sonsuza dek Tanrı'nın huzurundan kovulacağı sonucuna varmak, gerçekten dehşet vericidir (Crockett, 1996: 61). Adalet argümanına göre, sonlu bir günahın sonsuz cezayı hak etmesi tartışmaya açıktır (Seymour, 2007: 39). Bu argüman insanların işledikleri bütün günahların sonlu olduğuna dikkat çeker. Tarihteki en kötü kişiler bile sonsuz miktarda günah işlememişlerdir; Neron, Cengiz Han ve Hitler hepside nihayetinde sınırlı sayıda insana sınırlı miktarda zarar vermişlerdir. Üstelik cezaların işlenilen günah ile orantılı olması gerektiği bu argümanın ikinci temel teizidir. Örneğin küçük bir hırsızlığı ömür boyu hapis cezası ile cezalandırmamalıyız. Sonuç olarak, evrenselci görüşü savunanlara göre hiçbir insan sonsuz cezalandırmayı hak etmez, çünkü insanların günahları sonludur ve orantlılık ilkesi nedeniyle yalnızca sonlu bir cezayı hak ederler. Tanrı kusursuz bir şekilde adalet sıfatına sahip olduğuna göre $O$, insanları hak etmedikleri bir cezaya çarptırmayacaktı. Cehennem sonsuz bir ceza yeri ise, bu argümana göre Tanrı'nın herhangi bir insanı cehenneme göndermesi mümkün olamaz (Seymour, 2007: 37).

Anlaşıldığı üzere bu görüşte cehennem, bütün sakinlerini toplayan onları arındıran ve temizleyen bir ateşe dönüşüyor. Günahkârların cehennemde çekeceği ceza sonsuz olmayacak fakat herkes için kurtuluş ile sonuçlanacaktır. Bu, insana çekici gelen bir yorumdur çünkü bu görüşte hem Tanrı mutlak zaferini korur hem de günah da ciddiye alınmış olur. Aynı zamanda, gelenekselcilerin de kabul etmesi kolay bir durum, çünkü kurtuluşa seçilen insan sayısını da arttırmaktır. Bu yorum diğerlerine göre daha az sorun çıkaran bir yorumdur (Pinnock, 1996: 141-142)

Genel olarak ifade etmek gerekirse cehennem hakkındaki görüşlerin "Tutucu" ve "Liberal" görüşler diye ayrıldığını görüyoruz. Aşağıda biraz daha detaylandıracağımız bu görüşlere göre örneğin Liberaller, ölüm anında kurtuluşa erişemeyen bazılarına, ek şanslar verileceğine inanıyorlar. Liberal görüşün önemli temsilcisi ve Kötülük ve Sevgi Tanrısı isimli eserin yazarı John Hick, her ruha mükemmel olmak için ihtiyaç duyduğu kadar zaman verileceğini öne sürer (Seymour, 2007: 100). Hick, Liberal görüşler içerisinde en popüler olan evrenselcilik doktrinini Tanrı'nın iyiliği ve her şeye gücü yetmesine dayandırır; eğer Tanrı kusursuzsa, herkesi kurtarmak isterse, ve eğer Tanrı her şeye kâdirse, herkesi kurtarabilir (Hick, 2010: 196,247). Hick, gelenekselci cehennem inancında var olan sonsuza kadar cezalandırma fikrini reddeder (Van Holten, 1999: 45). Yine Clark H. Pinnock gibi geleneksel cehennem inancına karşı olanlar öncelikle böyle bir inanca duygusal bir tepki verirler. Pinnock'a göre cehennem inancı, İsa Mesih'te ortaya çıkan Tanrı'nın vahyiyle uzlaştıılamaz. O, sınırsız bir merhamet Tanrısı değil midir? Bu durumda böyle bir zulüm ve vahşet tanrısını nasıl tasarlayabiliriz? İnsanları sonsuz bir işkenceye tabi tutmak İsa'nın "Baba" sının 
yapacağı bir şey midir? Düşmanlarımızı bile sevmemizi söyleyen Tanrı, kendi düşmanlarından sonsuz bir intikam almak istemez. Pinnock'a göre intikam arzusunu acımasızca ve doyumsuzca tatmin etmeye çalışan bir kimse hakkında ne düşünürsek Tanrı hakkında da onu düşünürüz (Pinnock, 1996: 140).

Alternatif yorumlar içinde ilk görüş Ortodoks görüştür, bu görüşe göre Kutsal Kitap hem kötülüğün cezalandırılmasının sonsuz olduğunu hem de Tanrı'nın bir sevgi ve merhamet Tanrı'sı olduğunu vahyediyorsa, burada bir problem var demektir. Cehennem inancı ile ilgili ikinci görüş ise bir çok takipçisi de olan Metaforik yaklaşımdır. Kötülerin kurtarılmayacağını ve iflah olmayacağını kabul eden bu görüş, kutsal kitabın ortaya koyduğu acı çekme sahnelerini literal olarak ele almaz (Walvoord, 1996: 12-13). Metaforik yaklaşım, en ılımlı revizyondur, bu nedenle, geleneği onurlandırmak isteyenler için de en cazip olasılıktır. $\mathrm{Bu}$ yaklaşım cehennemdeki bitmeyen acıların mahiyetini metaforik anlamda yeniden gözden geçirmeyi içerir. Augustine elbette, böyle düşünenlere "Neden ateşin maddi olmadığını ve yakmayacağını düşünüyorsunuz?" diyerek karşı çıkmıştir (Pinnock, 1996: 141). Yaklaşık dört yüz elli yıl önce, kutsal metinlerdeki "Yabası elindedir. Harman yerini temizleyecek, buğdayını toplayıp ambara yığacak, samanı ise sönmeyen ateşte yakacak." (Matta 3:12) ifadesi gibi "ebedi ateş" in metaforik olarak daha doğru anlaşıldığını belirten kişi John Calvin'dir. Ona göre kutsal yazının birçok pasajından çıkarabileceğimiz şey, bunun [sonsuz ateş] metaforik bir ifade olduğudur. Calvin'den kısa bir süre önce ise Martin Luther, sanatçıların cehennem portrelerini reddetmiş ve onların hiçbir değerinin olmadığını söylemiştir. (Crockett, 1996: 44).

Bunların dışında Yok Olma Teorisi diye isimlendirebileceğimiz bir teori vardır. Bu teoriyi savunanlara göre de Tanrı’nın iyi bir varlık olduğu iddiasıyla klasik haliyle cehennem inancı birbiriyle bağdaşmaz. Pinnock gibilerinin düşüncesi olan bu düşünce imha etme ya da koşullu ölümsüzlük olarak adlandırılan üçüncü bir olasılığı gündeme getirir. Pinnock Tanrı'nın, günahkârlara sonsuz acı ve ölümsüzlük vermediğini, ancak sonunda nihayet yok olmalarına izin vereceğini ileri sürer (Pinnock, 1996: 142). Pinnock'a göre insanların sonsuzca ve acımasızca acı çekmeleri olağan ahlaki standartlarla ve/veya Kutsal Kitap'ın ruhuyla kıyaslandığında, Tanrı ile değil Şeytanla ilişkilendirilmesi daha kolay bir manzara ortaya çıkmaktadır (Akdemir, 2013a: 143). Bu teoriyi savunanlara göre ortaçağdaki cehennem inancı, Tanrı'yı kullarını seven, onların iyiliklerini isteyen merhametli bir varlık olmaktan çıkarıp daha çok sadist bir işkenceciye dönüştürüyor gibi görünmektedir (Clark, 2001: 15). Sonsuz cezalandırma Pinnock'a göre hiçbir olumlu işleve ve yapıcı amaca sahip değildir; o sadece, İncil' de açıklanan Tanrı'nın sevgisini geçersiz kılan bütünüyle bir kindarlık örneğidir. Bu münasebetle o Tanrı'nın ne iyiliği ile ne de adaleti ile bağdaştırılabilir. Onun geleneksel cehennem doktrinine yönelttiği felsefi nitelikli bir diğer eleştirisi ise daha önce de değindiğimiz gibi, bu doktrinin kabul edilmesinin Tanrı'nın kendisini kozmolojik bir düalizme mahkûm ettiği şeklinde bir sonuç üreteceği yönündeki endi- 
şedir. Şöyle ki, şayet cehennemin de Tanrı'dan bağımsız, zorunlu olarak ebedi bir varlık olma imkânını kabul edecek olursak, bu Tanrı dışında bir diğer sonsuz ve bağımsız varlığı kabul etmemiz anlamına gelecektir ki, özelde Hristiyan teolojisi genelde ise teizm için onaylanamaz bir görüştür bu. Oysaki Pinnock' a göre, mutlak kudret ve mükemmel düzeyde iyilik sıfatlarına sahip bir Tanrı' dan dan bizim beklediğimiz ve ona da yakışan, tarihin sonunda hem kendi zaferini ilan etmesi hem de insanoğlunu kurtuluşa, mutluluğa erdirmesidir (Akdemir, 2013a: 145-146). Ancak o, iddiasını yukarıda söylediği gibi genel bir izlenime dayandırmakla da yetinmez. İncil'deki spesifik ifadelere/saptamalara müracaat ederek bu ifadelerin kendi görüşünün kitabi dayanakları olduğunu söyler. Örneğin, Yeni Ahit'te geçen, Tanrı'nın, "ruh ve bedenin yok edilmesinin kendi kudreti dahilinde olduğu" (Matta 10:28), benzetme yoluyla "iyi meyve vermeyen her ağacı ateşe atacağı" (Matta 3:10), "buğdayı ambara yığıp, samanı ise yakacağı" (Matta 3:12) şeklindeki İncil ifadelerinin Tanrı'nın kaybedenleri sonsuza kadar cehennemde yakmayıp aksine cehennem ateşi ile yokluğa göndereceğini daha fazla desteklediği iddia eder (Akdemir, 2013a: 150).

Günümüzde ise Hristiyan filozoflar arasında Hristiyan teizminin en popüler versiyonu, Thomas Talbott'un Ilımlı Muhafazakâr Teizm adını verdiği versiyondur. Cehennemle ilgili ılımlı muhafazakâr teizm Tanrı'nın kusursuz bir şekilde ve evrensel olarak merhametli olduğunu kabul eder ve bu nedenle de bazılarının lanetlenmiş olduğu fikrini reddeder (Reitan, 2002: 429-430). Yani Talbott cennetin ve cehennemin varlığının aynı anda imkânsız olduğuna inanır. Tanrı'nın tüm insanların kurtuluşunu sağlaması zorunludur ve Talbott'a göre, Tanrı, bu sonucu ortaya çıkarmak için belki de bizleri (cehennem inancı ile) tamamen aldatiyordur. Fakat bu argümanların hakıılığını tartş̧madan önce daha ayrıntılı olarak ilahi iyiliğin ne anlama geldiğini sormamız gerekiyor. Örneğin günümüz düşünürlerinden Eleonore Stump, Tanrı'nın iyiliği kavramını doğru bir şekilde tanımlayarak, onu cehennemin varlığıyla bağdaşttracağımızı düşünüyor (Seymour, 2007: 95). Yine William Lane Craig, cehennemdeki cezanın Tanrı'nın adalet ve sevgisiyle tutarlı olduğuna inanır çünkü İsa'yı reddetme konusunda iyi bilgilendirilmiş bu özgür karar vericiler yani insanlar aslında Tanrı tarafindan değil kendileri tarafindan cezalandırılmışlardır (Craig, 1989: 176). Craig Tanrı'nın, bazı kişilerin kendilerini özgürce lanetlemelerine izin vermesinin ve bu insanların kaybetmiş kişiler olarak sonsuza dek sefil ve acı içinde olmalarının en azından mantiksal olarak mümkün olduğunu düşünür (Talbott, 1992: 508).

\section{Cehennem İnancı Etrafında Tanrı'nın Ahlakiliği ve Bazı Sıfatları ile İlgili Ortaya Çıkan Tartışmalar}

Cehennem inancı ilgili en büyük problem, Tanrı'nın ahlaken mükemmel olduğu, yani Tanrı'nın daima ahlaki açıdan doğru olanı yaptığı varsayımı üzerine ortaya çıkar. Bazıları, Tanrı'nın iyiliğinin, ahlaki açıdan iyi olmayı zorunlu olarak içerme- 
sini reddetmiştir (Van Holten, 1999: 40-41). Brian Davies gibi düşünürlere göre Tanrı'nın bir şekilde, ahlakın üstünde ya da ötesinde olduğu düşünülmelidir (Davies, 1993: 50). Din felsefecilerinin çoğu bu görüşleri kabul etmezler çünkü onlar Tanrı'nın yarattıklarına karşı ahlaki sorumlulukları olduğunu düşünürler (Seymour, 2007: 44). Tanrı'nın ahlakiliği ve bazı sıfatları ile ilgili ortaya çıkan tartışmaların gelenekselci cehennem inancı ile ilgili olduğunu görmekteyiz. Zaten evrenselci görüşün ve diğer alternatif yorumların ortaya çıkmasının sebebi de büyük ölçüde bu problemdir.

Geleneksel teizm dolayısıyla da gelenekselci cehennem inancı Tanrı'nın insanların tabi olduğu ahlak prensiplerine tabi olduğunu kabul etmez. Bu minval üzerine ahlakın bizim üstümüzde olduğunu ve doğru olanı yapmadığımız zaman ahlaki ilkelerin bizleri yargıladığını söyler. Tanrı zaten ahlakın taleplerini mükemmel ve zorunlu olarak yerine getirir; aslında, onun iyiliğini anlatmanın en iyi örneği Tanrı için yanlış bir şey yapmanın imkânsız olduğudur. Bu durumda ahlak bizim için vardır, Tanrı için değil sonucu ortaya çıkar (Kvanvig, 1993: 114).

Eğer Tanrı ahlaktan öte ise, o zaman Tanrı'nın yaptığı hiçbir şey, kötülük ya da haksızlık olarak nitelenemez. Bu durumun en bariz ve sakıncalı kusuru, Tanrı'nın mükemmel olduğuna karar vermeyi sağlayan nitelik ya da nitelikleri Ona yükleme olasılığını ortadan kaldırmasıdır. Bununla birlikte, bu sonucun bedeli vardır çünkü Tanrı'nın ahlakın üstünde olması durumunda, Tanrı'nın yaptı̆̆ hiçbir şeyin doğru ya da iyi olduğu da söylenemez; eğer biri bu yöntemi takip ederse, Tanrı'nın niteliği ve eylemleri hakkında, Tanrı'nın Tanrı olduğu ifadesinden daha fazla bilgi vermeyen önemsiz bir hakikate ulaşmış olacaktır. Bu sorunlara yol açan yanlışlık, tek tanrılı dinler geleneğinde uzun ve etkileyici bir geleneğe sahip olan Tanrı'nın egemenliğini koruma arzusunda değil, Tanrı ile diğer varlıklar arasındaki ilişkinin felsefi olarak nasıl anlaşılacağı ile ilgili durumda ortaya çıkar. Belki burada söylenilecek olan şey, Tanrı'nın iyiliğinin anlaşılmasının bağlayıcı ahlaki kurallarının insanları bağlayan ahlaki kurallar gibi olmamasıdır (Kvanvig, 1993: 113-114).

Tanrı'nın bir şekilde, ahlakın üstünde ya da ötesinde olduğu düşünüldüğünde başka bir durum daha ortaya çıkar. Örneğin bir Hristiyan, Tanrı'nın ahlaki açıdan kötü bir şey yapmayacağına, mesela soykırım yapmayacağına nasıl emin olabilir (Van Holten, 1999: 40-41). En azından Augustine'e kadar uzandığını iddia edebileceğimiz uzun teolojik geleneğe göre, Tanrı'nın adaleti ve merhameti birbirinden farklı şeylerdir. Ve bu gelenek Tanrı'nın merhamet ve adaletinin Ona ait farklı ve zıt nitelikleri olmadığını, tam tersine bu niteliklerin birbirini tamamlayan nitelikler olduğunu savunur (Talbott, 1993: 151-152).

Geleneksel görüş bazı köklü itirazlara maruz kalır. Geleneksel görüşe karşı çıkanlara göre bu konuda yüzleşilmesi gereken ahlaki ve metafizik sorunlar vardır. Tanrı'nın iyiliğiyle çelişen ve ahlak tasavvurumuzu bozacak şekilde hareket ettiğini tasvir eden geleneksel görüşü çevreleyen ahlaki sorunlara genel olarak 
bir bakalım. Hristiyan teolojisine göre Tanrı, İsa Mesih'te sınırsız merhamet olarak kendisini gösterir. Tanrı tüm dünyayı yani içindekileri sever. Incil'deki ifadelere baktığımızda (Örneğin Luke 15:11-32), geleneksel görüşün ileri sürdüğü gibi Tanrı sadist ve acımasız bir işkenceci değil, günahkarlara karşı bile affedici ve sevgi dolu bir Baba'dır. Buna rağmen Tanrı'nın insanlara sonsuza kadar eziyet edeceğini savunan gelenekselci cehennem inancını kabul ettiğimizde Tanrı'nın affediliğini ve sevgisini nereye koyacağız? Cehennemin nasıl bir yer olduğu ile ilgili gelenekselci görüş, İncil'de ortaya konulan Tanrı'nın sıfatları ile tam olarak bağdaşmaz; öyleyse cehennemin sonsuz cezalandırma olduğunu iddia etmeden önce iki kez düşünmeliyiz (Pinnock, 1996: 149).

Geleneksel görüş karşıtlarına göre sonsuz işkence, ahlak temelinde kabul edilir bir şey değildir. Çünkü bu düşünceye göre Tanrı, ölmesine bile izin vermediği düşmanlarına sonsuz bir Auschwitz ${ }^{3}$ hayatı sürdüren, kana susamış bir canavar gibi davranır. Herhangi biri böyle bir Tanrı'ya nasıl sevgi duyabilir? Bu durumda ondan korkulacağı kesindir ama onu sevip saygı duyabilir miyiz? Üstelik sonsuz ve kasıtlı işkence fikri, kötülük problemini de çözülmesi zor seviyelere getirmektedir. Bu durumda eğer Hristiyanlar Tanrı'nın bazılarını sonsuza kadar cehennemde işkence etme niyeti ile yarattı̆ına gerçekten inanıyorlarsa, Hristiyanlığı savunmak için gösterdikleri çabadan vazgeçmeliler diyen Antony Flew gibilerine firsat verilmiş olur (Pinnock, 1996: 149-150).

Geleneksel görüşe katılmayanlara göre cehennem inancı ahlaki testi geçmek zorundadır ve Pinnock ileri sürdüğü versiyonun bunu yapabileceğini düşünür. Yukarıda Pinnock'un savunduğunu ifade ettiğimiz Yok Olma Teorisi'ni savunan biri, sonsuz işkenceyi savunmak zorunda değildir ve insan özgürlüğüne yönelmiş olan bu kişi, cehenneme ilahi kader noktasında bakmak zorunda değildir. Pinnock'a göre, Tanrı günahkârlara kötü davranmada haklıdır ve bunda ahlaki olarak bir sorun yoktur çünkü Tanrı insan seçimlerine saygı duyar. Günahkârlar kurtarılmayı istemedikleri için Tanrı onları kurtarmayacaktır. Tanrı elbette bütün insanların kurtuluşunu ister fakat insana verilen özgürlük nedeniyle onlardan bir kısmı kurtarılmayacaktı. Aslında cehennemin var olduğunu iddia etmek varoluşsal anlamda insana önem vermek anlamına gelir. Adalet ilkeleri cehennemin mahiyetine ilişkin geleneksel inanç için ciddi bir sorun teşkil etmektedir çünkü Tanrı'nın adaletsiz hareket ettiğini tasvir etmektedir. Tanrı'nın karakteri hakkında sorulara yol açar ve doğal adalet duygumuzu bozar (Pinnock, 1996: 149). Pinnock sonsuz eziyetin hiç bir amaca hizmet etmediğini ve Incil'de vahyedilen Tanrı sevgisiyle bu kindarlığın uyumsuzluk sergilemekte olduğunu ortaya koymaya çalışır (Pinnock, 1996: 153).

\subsection{Cehennem İnancı ve Mutlak Adil Tanrı}

Anselm ve T. Aquinas gibi teologlar, insanlardan bazılarının cehennemde acılar içinde sonsuza kadar kalacağı inancını, Tanrı'nın mükemmel adaletinin bir gere- 
ği olarak savunmuşlardır. Bu anlayışa göre, Tanrı, günahkar insanlara da günahsız insanlar gibi eşit davranırsa haksızlık etmiş olur (Adams, 1975: 433-434).

Son yıllarda Tanrı'nın ahlaki yasaya, en azından geleneksel anlayıştaki gibi bir ahlaki yasaya tabi olmadığına inanan Marilyn Mccord Adams gibi filozoflar vardır; bu teolojik kabule göre, cehennem öğretisine karşı adalet argümanı ileri sürülemez. Ona göre Tanrı hiçbir şeye hiçbir zaman haksızlık etmeyeceği için Tanrı'nın adaleti diye bir problem söz konusu olamaz. Bu, adalet argümanına cevap vermenin en basit yoludur fakat din felsefecileri için cazibesi sınırlı olmuştur. (Seymour, 2007: 44). Adams'a göre cehennem Tanrı'nın adaletinin bir gereğidir. Ancak sorun burada adaletin nasıl anlaşılacağıdır. Ona göre gerek insani planda gerekse tanrısal planda adalet şu üç ilke üzerine kuruludur: (1) benzer durumlarda benzer şekillerde davranmak anlamında eşitlik, (2) bir kimseye hak ettiğinden daha kötü davranmamak ve (3) bir kimseye hak ettiğinden daha iyi davranmamak anlamında denklik. Adams'a göre, sonlu dünyevi yaşamlarındaki sınırlı sayıdaki/ miktardaki hataları nedeni ile insanların sonsuz bir cezaya ve mutlak bir mutsuzluğa mahkûm edilmeleri (1)inci ilke ile uyumlu iken, (2)inci ve (3) üncü ilke ile uyuşmamaktadır. Ayrıca o, sadece adaletle değil, Hristiyanlıktaki sevgi ve merhamet Tanrı'sı fikri ile de çelişmektedir. Sonsuzca çekilen bir acı Tanrı'nın sevgisi ve merhameti konusunda başarısızlığa uğradığı anlamına gelmektedir. Kitab-ı Mukaddes'te ifade edildiği şekliyle tanımlanan bir Tanrı hiç kimsenin ebedi olarak mahvolmasına ya da sonsuzca acı çekmesine müsaade etmemelidir. Aksi takdirde, yani bazı kimseler ebedi olarak cehenneme mahkûm edilecek olursa bu, tanrısal planın başarısızlığa uğradığı anlamına gelecektir ki, bunun da ilahi amaçlar düşünüldüğünde kabul edilebilir bir tarafi yoktur. Çünkü cehennem sonuçta herkesin arınmasına ve kurtarılmasına yardımcı olmayacaksa, yani iyi bir amaca hizmet etmeyecekse bizatihi kendisi paradigmatik bir kötülük örneği olarak kalacaktır (Akdemir, 2013b: 121).

Anlaşılan o ki adalet ve sevgiden oluşan bu resme bütün olarak bakmadığımız sürece cennetin ve cehennemin varlığını açıklayamayız. Burada önemli olan Tanrı'nın bu sıfatlarından hangisinin baskın olduğudur. Tanrı'nın sevgisi adaleti tarafindan sınırlanıyor mu? Yani Tanrı'yı motive eden esas sıfatı adaleti midir? Nicolas Malebranche ikinci görüşü savunur. Ona göre, adalet Tanrı'nın yüce ahlaki özniteliğidir, diğerlerinin tümü ona tamamen bağlı ve ondan türetilmiştir. Malebranche için, Tanrı ile onun yarattıkları arasındaki ilişkinin her yönü adalet sıfatına dayanır (Kvanvig, 1993: 117). Bazılarına göre bu görüşün de önemli zayıflıkları vardır. En önemlisi, eğer adalet Tanrı'nın temel motivasyon özelliği ise, bu yaratılmışlar açısından zor bir durumdur. Söz konusu olan adalet türü yani intikam adaleti aktif veya yaratıc olmaktan ziyade tepkiseldir. Adalet, zaten var olan halihazırda meydana gelmiş durumlara ve bireylere cevap vermemize yol açmaktadır. Oysa yaratıcı olarak varlığa sevgi ile yaklaşmak daha doğal olandır (Kvanvig, 1993: 117-118). 
Son iki asırda yaşamış filozof ve teologların birçoğuna göre geleneksel cehennem inancının düzeltilmesi gereken yerleri olduğu açıktır. Onlar bu öğretiden Tanrı'nın, yargılama gününde günahkâr olan insanları, bu yaşamdaki kötülükleri için bir ceza olarak sonsuza kadar azaba maruz bırakacağını anlamışlardır. 'Göze göz' ilkesi ve suçla doğrudan orantılı bir cezalandırma yükümlülüğü getiren diğer ilkeler, yalnızca, muazzam veya sonsuz sayıda kişiye sınırlı zarar veren fiilleri içermeyen davalara başvurulduğunda makul olabilir. Bununla birlikte, makul olan kendi sınırları içinde, insanın acı çekmeye ve bu dünyada insan yaşamının sınırlı uzunluğuna neden olacak sınırlı gücü göz önüne alındığında, yukarıda bahsedilen cehennem öğretisini haklı çıkaramazlardı. Eğer bir insanın, bu dünyadaki eylemleriyle, ebedi lanetlemeyi hak etmesinin bir ahlak ilkesi olmadığını düşünmekte haklıysak, o zaman düşündüğümüz cehennem öğretisi Tanrı'nın kusursuz adaletiyle ifade edilemez. Dahası, böylesi bir cehennem öğretisi Tanrı'nın mükemmel adaletiyle bağdaşmaz (Adams, 1975: 447).

\subsection{Cehennem İnancı ve Mutlak İyi/İyiliğin Kaynağı Tanrı}

Cehennem inancı, bazı kişilerin sonsuz mutsuzluk yaşayacağının mantıksal ve epistemik olarak mümkün olduğunu iddia eden inançtır. Cehennem karşıt görüşlerin çoğu da, bu inancın, Tanrı'nın iyilik sıfatı ile çeliştiğini savunurlar ve böyle bir vakıanın gerçekleşme ihtimalinin mantıksal olarak imkânsız olduğunu göstermeyi amaçlarlar (Seymour, 2007: 5). Geleneksel teizme göre Tanrı özsel olarak mükemmel iyidir sadece iyi değil iyiliğin bizzat kendisidir (Plantinga, 2003: 46). Tanrı ahlaken salt iyi (mahza hayr) dir (Peterson, 2006: 90). Onun mükemmel varlığının bir parçası olan iyi olma sıfatı ahlakın gereklerini ihlal etmez (Kvanvig, 1993: 114). Bir varlığı ahlaken salt iyi diye nitelemek için ne tür karakter özellikleri, davranış ilkeleri vb. gerekiyorsa, bunların Tanrı'da da var olduğunun kabul edilmesi gerekir. Fakat iyilik ve Tanrı arasındaki ilişkiyle alakalı temel soru, ahlaki iyiliğin kıstasının kaynağıyla ilgilidir. Tanrı'dan bağımsız olarak bir iyilik ölçütü var mıdır ki, Tanrı da bütün diğer kişiler gibi ona uymaya mecbur olsun (Peterson, v.dğr., 2006: 90)? Konumuz ile ilgili problem ise cehennemin mükemmel derecede iyi olan Tanrı tarafindan yaratılıp yaratılmayacağıdır.

Aquinas eserlerinde tanrısal iyiliğin tanımını yapmıştır. Aquinas'a göre iyiliğin özü onun bir şekilde arzu edilebilen olmasıdır. İyilik herkesin arzuladığı şeydir. Apaçık olan bir şeyin sadece mükemmel olduğu ölçüde arzu edilebilir olduğudur, zira her şey kendi mükemmelliğini arzular. Ancak her şey gerçek olduğu sürece mükemmeldir. Öyleyse bu durumda bir şey var oldukça mükemmeldir, zira her şeyi gerçek kılan var olmaktır. Böyle olunca iyilikle varlığın gerçekten aynı şey olduğu ortaya çıkmış olur (Aquinas, 1981: 29-30). Ancak bu şu anlama da gelmemelidir: Örneğin var olan bir şeyin ziyadesiyle var olması daha iyi olduğu anlamına gelmez. Tıpkı şişman bir başkanın daha iyi bir başkan 
olacağı gibi. Bir şeyin varlığı ve dolayısıyla iyiliği, daha fazla kütleye sahip olması değil, mahiyetinin gereğini yerine getirmesiyle artar. Bir insan, insanlığın daha mükemmel bir örneği haline gelerek varlık ve iyilik kazanır, daha büyük ve cüsseli olarak değil. Aquinas'ın bakış açısına göre sevgi, kısmen sevilen şeyin iyiliğinin arzusudur. Bir şey için en iyisini yapmak onun varlığını tamamlamasına yardımcı olmaktır. Varlığını tamamlamasına yardımcı olmak kendisini ifade etmesine yardımcı olmaktır. Örneğin, bir çiçeğin mahiyeti, bu türlere uygun olan ışık, su ve besin miktarını vererek çiçek türlerinin oluşmasıyla türler tarafindan tanımlanır. İnsanın mahiyeti, iyiliği sevmek ve akla göre yaşamaktır. Tanrı nihai iyilik olduğu için, bu, insanların mahiyetlerin en iyi şekilde Tanrı'yı sevmek ve O’na itaat etmekle ifade ettikleri anlamına gelir. Peki, Tanrı'dan yüz çeviren ve boğazına kadar kötülüğe batmış olan insanlar? Tanrı bu ruhları yok etmeli mi? Bu, sevgi dolu bir karşılık olmayacaktır, çünkü yok olma, varlığın mutlak olarak ortadan kaldırılmasıdır. Sevgi sevilen şeyin iyiliğini arzular, ama iyilik ve varlık aynı olduğu için yok etme sevilmeyecektir. Bu yüzden Tanrı, var olanı korur ve onların mahiyetlerinin gereğini olabildiğince çok yerine getirmelerini sağlar. Varlığın tam bir yok oluşu olarak ölüm yani yok olmak Thomistic görüşte en kötü şey olsa gerektir. Buradan çıkan sonuç Tanrının öte dünyada kullarını sonsuza kadar yaşatacağıdır (Seymour, 2007: 96).

Aquinas'ın teorisi diğer filozofların dikkatinden kaçmamış ve onların eleştirisinden kurtulamamıştır. Bu görüş ile ilgili eleştirilerden biri iyilikle varlığın özdeşleştirilmesi meselesidir. Kvanvig'in ortaya koyduğu gibi, "Birisini sevmek, yalnızca o kişi için nesnel olarak iyi olanı değil, aynı zamanda en derinden istediği şeyi - en azından nesnel olarak iyi olanla çelişmediği sürece istemektir. Koleje gitmek bir kişi için objektif olarak en iyisi olabilir, ama eğer kişi çalışmaktan yorulduysa ve bunun yerine bir işte çalışmak isterse, ebeveyni bu kişinin isteğine saygı göstermelidir (Seymour, 2007: 99). Yaradan'ın yaratkklarına olan özenini ve ilgisini anlatmak için ebeveynin çocuklarına olan ilgisi, Kutsal Yazılar tarafindan bize sunulan paradigmadik bir metafordur (Walls, 2009: 15-16). Yine ebeveyn analojisi ile ilgili başka bir örnekte gazla dolu bir odada bir ebeveynin iki yaşındaki çocuğu elindeki çakmakla başbaşa bırakmasıdır. Çocuğun gazı ateşleme ya da ateşlememe kararı gerçeğine rağmen bu ebeveyn yine de zalim olacaktır. Bizler de Tanrı'nın çocuklarıyız, her ne kadar iradeli varlıklar olarak yaratılmış olsak da çok fazla günaha sokulma potansiyeli ve çarpık gerçeklik algısı ile karşı karşıyayız. Çocukları olarak Tanrı'nın ezeli kaderimizle ilgili durumu bizim seçimlerimize bırakması zalimlik olur (Seymour, 2007: 100).

Tabii ki, bir şeyi sevmek iyiliğini desteklemeyi içeriyorsa, Tanrı'nın nasıl sevilebileceğini merak edebiliriz, çünkü Tanrı'nın iyiliği mükemmeldir ve bu iyiliğin zamanla gelişen ya da terfi kat eden bir yapısı yoktur. Ama burada basitlik doktrini hatırlamak yardımcı olur (Stump, 1986: 193). Aquinas'a göre Tanrı basittir, iyiliği ile özdeştir; Yani, bir anlamda, ilahi tabiatın kendisinin üstün iyilik 
olduğunu söylemek doğrudur (Stump, 1986: 186). Anlaşıldığı üzere Aquinas ve onun gibi düşünenlere göre Tanrı'nın insanı yok etmeyip cehennemde bile sonsuza kadar yaşatması esasen iyiliktir. Yok etse idi bu kötülük olacakt. Ayrıca yukarıdaki itiraza başka bir cevap da Tanrı'ın yarattğı her şey iyi olduğu ve ancak gereği gibi kullanıldığında bizi mutlu edebileceği görüşüdür. Dahası, yarattı̆ı her şey bir anlamda onun yansımasıdır. Ancak dikkat etmeliyiz ki, onlar sadece Tanrı'nın bir yansımasıdır; Tanrı değillerdir (Walls, 2009: 103). Tanrı'nın iyiliği ifadesinin başka bir anlamda, yani metafizik anlamda düşünülmesini gerektiğini ifade edenler de olmuştur. Bazılarına göre de cehennem inancı ile Tanrı'nın iyi olması arasındaki çelişkiyi, cehennem inancına bir ayar vererek değil, ilahi iyilik kavramını yeniden yorumlayarak çözmeye çalışımalıyız (Van Holten, 1999: 40-41).

\subsection{Cehennem İnancı ve Mutlak Merhamet ve Sevgi Sahibi Tanrı}

Geleneksel Hristiyan teolojisi, Tanrı'nın insana yaklaşımını öncelikle sevgi temelinde tanımlar. Peki neden sevgiden adalete geçiliyor? İnsanlık bu konuda olumlu davranmadığı zaman, ortaya çıkan durumun bir karşılığı olması için Tanrı'nın adaletine başvurulmaktadır. Gelenekselci cehennem inancını savunanlar cehennem hakkındaki sorulara sıklıkla Tanrı'nın sadece sevgi dolu bir Tanrı değil, aynı zamanda mutlak adil bir Tanrı olduğunu hatılatarak yanıt verirler (Kvanvig, 1993: 108). Fakat inananlar için Tanrı sadece kendisine inanılan bir varlık değil sevgi dolu bir varlıktır. Tanrı'nın adalet ve sevgi sıfatlarının cehennem inancı ile olan ilişkisi farklıdır. Illahi adalet ile cehennem arasında tutarı bir ilişki kurulabilirken, sevgi sıfatında tutarsız olma ihtimali vardır (Seymour, 2007: 95). Diğer yandan yukarıda kısmen ifade ettiğimiz gibi ilahi adaletin ilahi sevginin kullanımına sınırlar koyduğuna inanılır. Tanrı, yaratıkları için sevgide bile haksız davranmayacaktır. Thomas Talbott Tanrı'nın tüm insanlık için sevgi beslediğini düşünen birinin gelenekselci cehennem görüşünü sürdüremeyeceğini ısrarla savunur (Kvanvig, 1993: 108). Buradaki temel soru eğer Tanrı bir sevgi Tanrısı ise, herhangi birini cehenneme nasıl gönderebilir? (Walls, 2009: 103) Son dönem düşünürleri, geleneksel cehennem öğretisine, özellikle Tanrı'nın sevgisiyle açıkça çeliştiği için itiraz etme eğiliminde idiler. Örneğin, John Hick, cehennemi, sevgi dolu bir Tanrı'nın faaliyetlerini açıklayamayan 'günahkar bir hayal gücünün' ürünü olarak görür ve reddedilmesi gerektiğini ifade eder (Hick, 2010: 92). Hick'e göre böyle bir cehennem öğretisi Tanrı'nın sevgisiyle çelişir (Adams, 1975: 434).

Diğer taraftan sevgi, mahiyeti gereği zorlanabilecek, programlanabilecek ya da manipüle edilebilecek bir şey değildir. Daha ziyade, alındığı kadar özgürce verilmelidir. Yani sevgi karşıııkıdır. Tanrı'nın sevgi dolu bir varlık olduğunu düşünenler aynı zamanda onu sevenler olmalıdırlar. İnsanın Tanrı'nın arzu ettiği ilişki türüne girmesi ve onu sürdürmesi için, Tanrı'yı özgürce sevmeli, güvenme- 
li ve ona itaat etmelidir. Ki İncil'de de bunu destekleyen ifadeler vardır (Walls, 2009: 104).

Kutsal Kitabın ebedi cezayı haber verdiğini kabul edenlerden bazıları, yine de, bu kavramı, Tanrı'nın sevgisi ve lütfu gerçeğini göz önüne alarak hafifletmeye çalışırlar. Azaba duçar olacak olanların ebedi cezası ile ilgili kanıt onunla ilgili itirazların yorumsal değil teolojik olduğunu gözler önüne sermektedir. Bu, teoloji ya da bir yorum sistemi ile İncil'in tefsiri arasındaki yüzlerce yıldır var olan gerginliği ortaya koymaktadır. Böyle düşünenlere göre eğer tefsir nihai belirleyici ise, Kutsal Kitabın sonsuza kadar cezayı bildirmesinin tek doğru sonuç olduğu yüzeysel bir değerlendirme olacaktır. Aksi takdirde ortaya çıkan durum, sonsuz cezayı reddeden pek çok kişinin Kutsal Kitabın doğruluğunu ve kesinliğini hatta İsa'nın öğretilerini bile reddetmesi olacaktır. Sonsuz ceza fikrinin karşılaştığı ilk itirazın temelinde, Tanrı'nın bir sevgi ve merhamet Tanrı'sı olduğunun Kutsal Yazılar'da şüpheye mahal bırakmayacak şekilde açık bir şekilde var olmasıdır. Böyle düşünenlere göre bir kişinin, bir taraftan Kutsal Kitapta Tanrı'nın sevgisi ve merhametinin vahyedildiğini kabul etmesi, diğer taraftan aynı kitabın ebedi cezayı haber verdiğini kabul etmesi bir çelişkidir (Walvoord, 1996: 27). Yukarıda bahsettiğimiz llımlı Muhafazakâr Teizmi savunan Talbott gibi gelenekselci görüşe karşı olanlara göre bu durumda affetme ve cezalandırma aynı varlığa ait ve aynı amacı hedefliyorsa, günahkârların affetmeyi hak ettiği fikri, cezayı hak ettikleri düşüncesinden daha saçma değildir. Ona göre Yeni Ahit'in dikkatimizi yönlendirdiği benzetmeye daha yakından bakalım. Tanrı ile sevgi dolu bir ebeveyn arasındaki benzerlik. Seven ebeveynler genellikle itaatsiz çocuklarını affetme yükümlülüğünü kabul etmiyor mu (Talbott, 1993: 164)?

\section{Sonuç}

Cehennem inancı ve bu inanç etrafinda ortaya çıkan felsefi ve teolojik tartı̧̧malara baktı̆ımızda aslında konunun din felsefesindeki önemli güncel tartı̧̧malardan biri olduğunu gördük. Bu konudaki tartışmaların gelenekselci ve liberal görüş diyebileceğimiz iki ana damar üzerinde konumlandığını gördük. Gelenekselci görüşün Augustine’a kadar uzanan bir geçmişi olmasına rağmen liberal görüşün yaklaşık iki yüz yıllık bir geçmişe sahip olduğu anlaşılıyor. Anlaşılan o ki gelenekselci cehennem inancının son dönemlerde yaygın bir şekilde tartşılmasının nedeni bu inancın Tanrı'nın sıfatları ve kusursuz bir varlık olması ile çelişiyor olduğunun düşünülmesidir. Temel eleştiri eğer Tanrı kusursuzsa, adaletsiz bir şey yapamaz, yani sonlu varlık olan insanın günahlarını sonsuz bir ceza ile cezalandıramaz. Yine sonsuz merhamet ve sevgi sahibi ve iyiliğin kaynağı olan Tanrı'nın insanlara sonsuza kadar işkence etmesi düşünülemez. Böylece, cehennem inancı ile ilgili en büyük problem onun en başta bir ahlaki problem olmasıdır. Gelenekselci cehennem inancının yeniden yorumlanması ihtiyacını ortaya çıkaran da bu ahlaki problemin geçerliliğini halen devam ettirmesidir. 
Diğer taraftan cehennem inancı ile ilgili ortaya çıkan tutumların bir belirleyicisinin de kişinin sahip olduğu Tanrı anlayışı olduğu ortaya çıkmış bulunuyor. Nitekim Augustine, Anselm ve Aquinas gibi cehennem inancı konusunda gelenekselci/muhafazakar ekolü temsil eden filozof ve teologların Tanrı'nın sıfatlarının bir bütünlük içinde anlaşılması gerektiğini iddia ettiklerini görmekteyiz. Bu yüzden onların cehennem inancı konusunda Tanrı'nın sevgi, merhamet ve iyilik sıfatlarını görmezden gelmediklerini fakat bu inancın doğru bir yere oturtulabilmesi için de adalet sıfatına önemli bir vurgu yaptıklarını görmekteyiz. Yine onlar cehennem inancı konusunda Kutsal Kitabın söylediklerini metaforik olarak anlamak yerine literal olarak anlamayı tercih etmişlerdir. Konunun tamamen metafizik bir konu olması, bu yüzden de onların bu konuda spekülatif düşünceler ortaya koymanın faydasız olduğuna inanmaları onların böyle düşünmelerinde etkili olmuşa benziyor. Yine onların Tanrı́nın sıfatlarını anlamada analojik yöntemi kullanmaları böyle düşünmelerine etki eden başka bir konudur. Nihayetinde gelenekselci görüşün en önemli savunucuları ortaçağda yaşamışlardır. Dolayısıyla içinde bulundukları sosyo-kültürel ortam ve Kilisenin etkisini göz ardı etmemek gerektiğini düşünüyoruz. Nitekim ortaçağdan çıkıp yeniçağa ve modern çağlara doğru geldikçe kilisenin etkisinin azalması ile gelenekselci görüşün felsefi ve teolojik düşüncede etkisinin kırılmaya başladığını görmekteyiz.

Cehennem inancı konusunda özellikle son iki asırda din felsefecileri arasında gelenekselci tutumun eleştirildiğini ve bazıları tarafindan terkedilmeye başladığını, liberal bir tutumun benimsendiğini görmekteyiz. Metaforik Yaklaşım, Evrenselcilik, Yok olma teorisi ve Ilımlı Muhafazakâr Teizm gibi yaklaşımların ortaya çıkmasında hem kilisenin etkisinin azalması hem de modern çağın ortaya çıkardığı bazı düşünme biçimlerinin ve kavramlarının etkisi olduğunu görmekteyiz. Ortaçağda insana Tanrı karşısında biçilen rol sadece kulluk rolü yani itaat idi ve insan bu ilişkide edilgen bir pozisyonda idi. Fakat Avrupa'da yaklaşık olarak 17. yüzyıl civarında ortaya çıkmaya başlayan, zamanla tüm dünyaya yayılan toplumsal değerler sistemi ve organizasyonu olarak kendini sunan modernite, kendini genel anlamda gelenek ile karşıtlık ve ondan kopuş temeli üzerinde bina etmiş; bireysel, toplumsal ve politik yaşam alanlarının tamamında bir dönüşüme ya da değişime sebep olmuştur. Modernite sadece insanı ve sosyal hayatı etkilemekle kalmamış, teolojiyi ve din anlayışını da etkilemiştir. Ortaya koyduğu Hümanizm, İnsan Hakları, Özgürlük, Sekülarizm vs. kavramların ve ideolojilerin etkisiyle, mülkünde dilediğini yapan, yaptıklarının/yapacaklarının sebebi "vardır bir hikmeti" cihetinde sorulmayan, eleştirilmeyen, cezalandırıcı bir Tanrı yerine, seven ve merhamet eden bir Tanrı imajına daha çok vurgu yapılmasına sebep olmuştur. Nitekim teoloji ile antropoloji arasındaki ilişkiyi en güzel şekilde anlatan Ksenofanes (Öl. M.Ö 475) bunu şu sözü ile anlatmak istemişti. "Nitekim Habeşler tanrılarını kendileri gibi kara ve yassı burunlu; Trakyalılar sarışın ve mavi gözlü olarak düşünürler. Öküzlerin ve aslanların resim 
çizme kabiliyeti olsaydı onlar da Tanrılarını öküz ve aslan şeklinde çizerlerdi." Antropomorfik unsurları bünyesinde çokca barındıran bir din olan Hristiyanlıkta bunun en güzel örneği 'Tanrı'nın çocukları', 'Baba' kültüdür. Son dönem filozoflarından Talbott ve onun gibi düşünenler tarafindan ifade edilen ebeveyn örneği gelenekselci cehennem inancının eleştirisinde bol bol kullanılmıştır.

Son olarak gelenekselci cehennem inancı ve onun keyfiyeti ile ilgili son dönemde alternatif düşünce ve yorumların ortaya çıkmasının bir diğer sebebi de, bu konunun gelenekselci ekolün savunduğu haliyle ateistlerin elinde güçlü bir silaha dönüşmesinin önüne geçme düşüncesidir diyebiliriz. Son yıllarda özellikle Batı'da gerek ateizm, gerekse agnostisizmin ciddi bir yükselişe geçmesi, konuyla ilgilenen akademisyenleri, teologları ve filozofları Evrenselcilik, Metaforik anlayış, Yok Etme Teorisi ve Ilımlı Muhafazakâr Teizm gibi alternatif anlayışlara itmiş olabilir.

\section{Notlar}

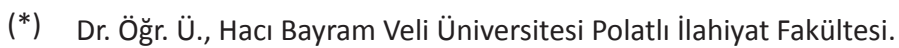
E-posta: tuncay.akgun@hbv.edu.tr

1 Matta, 25/41. Yeni Ahit, https://incil.info/arama/İşaya+66:24 (Erişim Tarihi: 21/10/2018).

2 Teolojinin sevap ve kurtuluş ile ilgilenen dalı

3 Auschwitz-Birkenau, Nazi Almanya'sı tarafindan II. Dünya Savaşı döneminde kurulmuş en büyük toplama, zorunlu çalışma ve sistematik katliam kamp.

\section{Kaynaklar}

Adams, M. M. (1975). Hell and the God of Justice. Religious Studies, (11)4, 433-447.

Akdemir, F. (2013). Clark H. Pinnock'un Felsefî Teolojisinde Geleneksel Cehennem İnancının Eleştirisi ve Yok-Etmeci Cehennem Anlayışının Savunusu. Milel ve Nihal: Inanç, Kültür, ve Mitoloji Araştırmaları Dergisi, X (1), 131-156.

Akdemir, F. (2013). Marilyn Mccord Adams'ın Din Felsefesinde Korkunç Kötülükler ve Cehennem Sorunu. Dokuz Eylül Üniversitesi Ilahiyat Fakültesi Dergisi, (II)38, 111-128.

Altundağ, M. (2007). Kur’an'da Müşkil Bir Mesele: Cehennem Azabının Ebediliği. Bakı Devlet Üniversitesi Ilahiyyat Fakültesi'nin Elmi Mecmuasi = Bakü Devlet Üniversitesi Ilahiyat Fakültesi'nin IImi Mecmuası, 7, 41-88.

Aquinas, T. (1981). Summa Theologica. Public Domain.

Burkert, W. (2009). Pleading for Hell: Postulates, Fantasies, and the Senselessness of Punishment. Numen, 56, 141-160.

Craig, W. L. (1989). "'No Other Name": A Middle Knowledge Perspective on the Exclusivity Salvation Through Christ, Faith and Philosophy, (6)2, 172-188.

Crockett, W. V. (1996). The Metaphorical View. Four Views on Hell. (Ed. W. Crockett, G. Rapids). Michigan: Zondervan.

Crockett, W. V. (1996). Response to John F. Walvoord. Four Views on Hell, (Ed. W. Crockett, G. Rapids). Michigan: Zondervan.

Davies, B. (1993). An Introduction to the Philosophy of Religion. U.S.A: Oxford University Press. 
Dawkins, R. (2006). The God Delusion, Great Britain: Bantam Press.

Eflâtun (1989). Phaidon. (Çev. S. K. Yetkin, H. R. Atademir). İstanbul: M.E.B Yayınları.

Gale, R. M. (1996). On the Nature and Existence of God. Cambridge: Cambridge University Press.

Hayes, Z. J. (1996). The Purgatorial View. Four Views on Hell, (Ed. W. Crockett, G. Rapids). Michigan: Zondervan.

Hick, J. (2010). Evil and the God of Love, U.K: Palgrave Macmillan.

Holten, W. V. (1999). Hell and the Goodness of God. Religious Studies, (35)1, 37-55.

Kvanvig, J. L. (1993). The Problem of Hell. Newyork: Oxford University Press.

Leftow, B. (2010). Eternity. A Companion to Philosophy of Religion. (Ed. C. Taliaferro, P. Draper and P. L. Quinn). U.S.A: Blackwell Publishing Ltd.

Leibniz, G.W. (2007) Theodicy.(Ed. Austin Farrer, Trans. E.M. Huggard) U.S.A: Bibliobazaar.

Nietzsche, F. (2008). On the Genealogy of Morality, (Ed. K. Ansell-Pearson, Trans. C. Diethe). Cambridge: Cambridge University Press.

Mill, J.S. (2009). Three Essays on Religion. Reprint ed., (Ed. L. J. Matz). Canada: Broadview Press.

Peterson, M., Hasker, W., Reichenbach, B., \& Basinger, D. (2006). Akıl ve Inanç-Din Felsefesine Giriş. İstanbul: Küre Yayınları.

Pinnock, C. H. (1996). The Conditional View. Four Views on Hell. (Ed. W. Crockett, G. Rapids). Michigan: Zondervan.

Plantinga, A. (2003). Does God Have a Nature? Milwaukee-Wisconsin: Marquette University Press.

Reitan, E. (2002). Eternal Damnation and Blessed Ignorance: Is the Damnation of Some Incompatible with the Salvation of Any? Religious Studies, (38)4, 429-450.

Seymour, C. (2007). A Theodicy of Hell. Netharlands: Springer.

Seymour, C. (1997). On Choosing Hell. Religious Studies, 33(3), 249-266.

Strickland, L. (2009). Leibniz on Eternal Punıshment. British Journal for the History of Philosophy $(17) 2,307-331$.

Stump, E. (1986). Dante's Hell Aquinas's Moral Theory, and the Love of God. Canadian Journal of Philosophy, (16)2, 181-198.

Swinburne, R. (1993), The Coherence of Theism, Oxford: Oxford University Press.

Swinburne, R. (1998), Providence and the Problem of Evil. Oxford: Clarendon Press.

Talbott, T. (1992). Craig on the Possibility of Eternal Damnation. Religious Studies, (28)4, 495510.

Talbott, T. (1993). Punishment, Forgiveness, and Divine Justice. Religious Studies, (29)2, 151168.

Tunçbilek, H. S. (2006). İslâm Düşüncesinde Cehennemin ve Cehennem Azabının Ebediyeti ve Fenası Problemi. Çukurova Üniversitesi Ilahiyat Fakültesi Dergisi, (6)1, 15-33.

Walls, J. L. (2009). How Could God Create Hell? God Is Great, God Is Good: Why Believing in God Is Reasonable and Responsible, (Ed. W. L. Craig, C. Meister). U.S.A: InterVarsity Press.

Walvoord, J. (1996). The Literal View. Four Views on Hell. (Ed. W. Crockett, G. Rapids). Michigan: Zondervan.

Wierenga, E. R. (1989). The Nature of God: An Inquiry into Divine Attributes. U.S.A: Cornel University Press. 